\title{
Charles I and the Earl of Glamorgan
}

THOUGH the time has, I hope, arrived when it is possible to examine the difficult questions arising out of the Glamorgan tresty with complete impartiality, it must be remembered that these questions are not to be solved even by the most impartial person who approaches the subject from a purely antiquarian point of view. An antiquary, indeed, may give useful information, to be received with all due respect, but unless he is familiar with the history and correspondence of the time, he does not know what is probable or improbable, and is, therefore, almost certain to draw wrong inferences from the facts which he has laboriously collected.

It is the more necessary at present to keep this in view, as the latest contribution to the controversy, which has long been carried on, is an article in the Academy for $8 \mathrm{Dec}$. 1883, by Mr. Roond, who adduces the authority of the great antiquary Dugdale in favour of the view that a patent of Charles I brought forward by Glamorgan after the Restoration, as creating him a duke, was a forgery, from which Mr. Round draws the further conclusion that Glamorgan may very likely have also forged other documents prodaced by him as his warrant for entering into his notorious treaty with the Irish in 1645.

With Mr. Roond I hare no wish to enter into controversy. After a good deal of friendly correspondence, he has, I think, been convinced by my arguments that several if not all of his obiter dicta on this matter will not hold water, and it will be better to state my own view as I proceed rather than to controvert those which were expressed by him.

At all events, we have to thank Mr. Round for drawing attention to Dugdale's opinion.

This (says Dugdale, writing on 5 Aug. 1660, after Glamorgan had succoded to the marquisate of Worcester of the patent referred to above) being in trath suspected to be forged, there appearing no vestige of it at the signet or privy seal, nor any other probable way, and my lord of Hartford being prepared to make such objections against it as might have tended much to the dishonour of my lord of Worcester before a committe of Iords-abont three days since, the marquis of Worcester was pleased to tell the lords that he must confess that there were certain private considerations upon which that patent was granted to him by the late king, 
which he performing not on his part, he would not insist thereon, but render it to his majesty to cancel if he so pleased.

In estimating the value of this statement it must be remembered that Dagdale was likely to be biassed in two ways. In the first place he was likely to think ill of a man whose whole story if true was discreditable to the royal martyr. In the second place, as an official, he was likely to think ill of a docament which was not officially correct, and to suppose that the best explanation of its irregularity was that it was forged in 1660 . If it can be shown that there is strong ground for supposing that in spite of the irregularity of the document it had actually passed under the eye of Charles I, we may safely refuse to follow Dugdale in the inference which he drew, in necessary ignorance of facts of which we are now cognisant.

In itself the question of the irregularity of this dukedom patent would only indirectly concern an inquirer into the Glamorgan treaty; but it is closely connected with another patent granting to Glamorgan a commission conferring on him very extraordinary powers to command an army in chief, and embodying the 'certain private considerations' referred to by Dugdale, and paving the way for his subsequent employment in Ireland. It is, therefore, necessary to come to some anderstanding on the history of both these patents before proceeding to that of the later documents which Glamorgan produced in Ireland. As Mr. Round says, if both or either of these were forged in 1660 , there is an end of Glamorgan's credit, and the warrants which he prodaced to justify his conduct in Ireland mast be regarded with grave suspicion. If, on the other hand, they were, however irregular, produced at an earlier date with Charles's knowledge and by his orders, the whole argament is inverted, becanse the extraordinary nature of the language in which they are conched makes it likely that the later documents, extraordinary as they were, were also produced with Charles's knowledge and by his orders.

The commission patent has been printed in Collins's 'Peerage,' ed. 1812, i. 295. The dakedom patent exists in copy in the Carte MSS. coix. fol. 349 , and in the original in the moniment room at Badminton, to which I have been allowed access through the courtesy of his grece the Dake of Beanfort. A hostile opinion of the former, which is not now to be found at Badminton, by Anstis, garter king of arms in the middle of the eighteenth century, is embodied in 'The Case of the Royel Martyr' (p. 141), the authorship of which is ascribed to Carte, and an opinion also by Anstis, less hostile but decidedly unfriendly to the dukedom patent, follows the copy of it in the Carte MSS.

Before examining the evidence of seals and signatures, let us fir the dates of these two patents. The commission is granted plainly 'at Oxford on the first of April in the twentieth year of our reign, and the year of our Lord one thousand six hundred and forty-four.' 
The dukedom is granted quarto die Maii anno regni nostri ricesimo primo, that is to say 1645. Anstis, however, in whose hands the original had been, perceived that primo is written in different ink from the rest of the date, and this is quite clear upon an inspection of the document itself, the word being now quite black, whilst the remainder of the writing has faded into brown. It may, therefore, be taken for granted that the real date is 4 May 1644, rather more than a month after the commission patent.

Waiving for the present all questions arising from the insertion of the word primo, let us ask whether there is anything in the documents themselves inconsistent with the date 1644. In this inquiry it will be better to begin with the commission patent.

The principal concessions there made to Glamorgan are as follows :

1. To be generalissimo of three armies, English, Irish, and foreign, and aamiral of a fleet at sea, with power to appoint officers.

2. To obtain the money needed for these purposes by contracting for the sale of wardships, customs, woods, \&c.

3. To distribute patents of peerages or baronetcies sealed in blank ' to 'persons of generosity,' as a means of making money.

4. Glamorgan's son is to receive in marriage the king's youngest daughter, Elizabeth, with a portion of $300,000 l$.

5. The title of duke of Somerset is to be given to him and his heirs for ever, and also the garter.

No doubt these are startling concessions. The second and third, however, were only means of raising money for the king; and the fourth, which is very startling indeed, is corroborated by a letter written by the king to Glamorgan's father, the first marquis of Worcester.

I will show (writes the king) my tender care of you and yours; as by a mstch propounded for your grandchild, you will easily judge, the partionlars of which I leave to your son, Glamorgan his relation."

Of the dukedom I shall have more to say presently, but the point of the greatest importance is the earl's appointment. to command by sea and land.

Here we have at least the advantage of hearing what Glamorgan had to say for himself. On 11 June 1660 he addressed as marquis of Worcester a letter to Clarendon, which is printed in the 'Clarendon State Papers' (ii. 201). ' Your lordship,' he says, 'msy

- The patent only says that the dates may be filled up, bat it is obvious the names wonld heve to be filled up too, either by Glemargan or the bing.

I Dircts, Life of the second Harquis of Worcuster, 103. Ho gives no date to the letter. I quote the correspondence of Charles with Glamorgan and his thether trom this book; bat the reader must bo on his gaerd against Mr. Dirchs'B ehronologg. Ho sometimes remembers and sometimes torgets that the year began on $25 \mathrm{March}$, and, amongst other consequent mistakes, makes Glemorgan 80 to Ireland trice in $164 \overline{5}$ insteed of once. 
well wonder, and the king too, at the amplitude of my commission.' He then explains how necessary it was, his majesty's design

being that one army of 10,000 men was to have come out of Ireland through North Wales; another, of a like number at least under my command in chief, have expected my return in South Wales, which Sir Henry Gage was to have commanded as lientenant-general ; and a third should have consisted of a matter of 6,000 men, 2,000 of which were to have been Liegeois, commanded by Sir Francis Edmonds, 2,000 Lorrainers to have been commanded by Colonel Browne, and 2,000 of such French, English, and Scots and Irish, as conld be drawn out of Flanders and Holland. And the 6,000 were to have been, by the prince of Orange's assistance, in the associated counties; and the governor of Lyne [King's Lynn], cousin german to Major Bacon, msjor of my own regimant, was to have delivered the town unto them.

Worcester then goes on to say that the pope and catholic princes were to support this army of foreigners, and that he had power to treat with the pope and catholic princes by offering the remission of the penal laws against the catholics.

One thing at least may be gathered from this letter. Glamorgan conld not possibly refer to a commission granted in 1645 , becsuse, as evervbody then knew, Sir Henry Gage was killed in January 164y. Here again, therefore, is an andesigned coincidence fixing the date of the patent to 1644 .

Were all these things, however, proposed by Charles to be done in 1644 ? Here I have only negative evidence to offer. It would be rash to assert that we know all of Charles's intrigues in 1645; but thanks to the letters seized at Naseby and Sherburn, we know a great deal, and we may fairly say that this plan of 1644 pas like that of 1645 with a difference. In 1645 there was an application to the pope for money to support an army, there was a plan for bringing an Irish army over, and another for bringing Lorrainers over with the help of the prince of Orange, bat there was no plan for bringing Liégeois over, as there had been as early as in 1641, and no plan for getting possession of Lynn, because by that time the attempt had been made by Roger L'Estrange and had failed. The plan, therefore, as explained in the letter to Clarendon, was just the sort of one to have been entertained by Charles, and wes yet one which if entertained at all could not have been thought of in $\mathbf{1 6 4 5 .}$

If, however, we have only Glamorgan's own evidence that auch a plan thought of in 1644, we may at least ask whether there is any reason to think it likely that it was so thought of. Curionsly enough the weeks between 1 April and $4 \mathrm{Mgy}$, the dates of the two patents, are the only weeks in the whole of 1644 in which Charles was in a position to entertain a project of the kind.

The backbone of the whole scheme was the proposed Irish army 
of 10,000 men. The notion of sending it was not Glamorgan's. It had come from the confederate catholics of Ireland, and its realisation depended on Charles's consent to certain terms which the agents of the catholics were to make at Oxford. These agents arrived towards the end of March 1644, and presented their conditions on the 29th. Writing on that day to Ormond, ${ }^{3}$ Digby, the secretary of state, expressed himself as doubtful, but not as despairing of saccess. On 2 April, however, Sir G. Radcliffe informed the lord lieutenant ${ }^{4}$ that the Irish had abated their demands. He then adds :

There is nothing that is scandalous now, nor dishonourable for the hing to treat on. I hear by another hand, not so good, I confess, yet reasonable good, that we shall have peace, and that they will submit mach to the king.

Surely, if Glamorgan forged his commission in 1660, he was singularly lucky in dating it on the day before this letter was written. It is true that the amended propositions, as we know from a letter of Digby's, were presented on the 2nd, not on the 1st, but the agents were pretty sure to let the king bnow a day or two before of their intention to amend them.

Again, it is only on 9 May, five days after the dukedom patent, that Digby ${ }^{5}$ writes that the feeling at Oxford is too strong against the proposals of the catholics to enable the king to grant their wishes, and it is as late as the 16th before Sir George Radcliffe abandons hope. 'I was till of late persuaded,' he writes, ${ }^{6}$ ' that we should have had peace. I now begin somewhat to doubt of it.' The negotiation was soon after this remitted to Ireland. Once more, if Glamorgan was a forger he chose his dates well.

The weeks between 1 April and 4 May were, therefore, precisely those when Charles was full of expectation of being able to come to terms with the Irish agents, precisely those in which he wanted a catholic commsnder for his expected new Irish army, and for any other foreign levies. whose co-operation he might hope to obtain. He also wanted a commander who was rich enough to enable him to start the financial operations which would form a necessary besis for the military enterprise. Such a man was Glamorgan, and it must therefore be accepted as at least historically probable that his story was a true one.

Such being the state of the case as far as historical evidence is concerned, let us turn to the documents themselves. It is true that there is no official evidence of their having been granted by the king. They were neither preceded by a royal sign manual nor by a privy seal, and they were not followed by enrolment on the patent rolls. Even if everything else had been regular it would have been

$$
\text { 'Carte's Ormond, vi. 81. + Tbid. 81. "Ibid. 109. - Ibid. } 120 .
$$


difficalt for the house of lords in 1660 , supposing the peers to have been better disposed towards Glamorgan than they were, to get over these defects. But this was not all. Not only was the English of the commission patent very unofficial in its character, but its seal was everything that it ought not to have been. As Carte reports from Anstis, it is composed of two grest seals clapped together so as to inclose the label. ${ }^{7}$ Such a patent could not possibly be accepted as valid. This is, however, no more than Glamorgan himself acknowledged with respect to the commission patent.

In like manner (he writes to Clarendon), ${ }^{8}$ did I not stick upon having this commission inrolled or assented to $b_{j}$ the ling's counsel, nor indeed the seal to be put unto it in an ordinary manner, bat as Mr. Endymion Porter and I could perform it, with rollers and no screw-press.

Endymion Porter, it will be remembered, wes believed to be associated with a similar performance in affiring the great seal to a docoment despatched to Ireland in 1641, just before the outbreak of the Ulster rebellion.

Is there any valid reason for supposing that this story is ontrue? Glamorgan, according to the hypothesis, was about to be employed in a secret mission. He wanted powers to enable him to fulfil it, and he wanted a reward after it had been fulfilled. Whether the docoments which gave him what he needed would satisfy judges or parliaments, he did not care a straw. If he succeeded, he would have done that which wonld reduce judges and parliaments to impotence. What be wanted was, in the case of the commission, something to convince those with whom he was about to treat that he was anthorised to treat, and this was precisely what he got, as the people with whom be had to deal in Ireland or on the continent were not likely to know whether his commission had been enrolled, or whether it had been preceded by a warrant or not, and not likely to examine the form of the seals very closely. As to the dukedom patent, it was equally without preceding sign manual or privy seal or subsequent enrolment, but the seal, which is now at Badminton, appesrs to be perfectly in order, and Anstis, who does not say that there was any fault with it, allows that Willis, who countersigned it, was the proper officer to do so. I should gather from this that though Charles wished the dukedom to be kept secret, there was no reason for such absolute privacy as in the case of the commission, and that Willis, if, as was probably the case, he was a trusty person, might be allowed so far to participate in the affair as to be present at the sealing of the patent.

Having resched this point, I must remind my readers that I have not undertaken to give positive proof that these patents were

The Case of the Royal Martyr, 142, 143.

- Clar. St. P. ï. 202. 
genuine. I have only attempted to show that the objections to them cannot be sustained, whereas the objections to the theory that they were forged in 1660 are very great indeed.

Let us now take up another objection which has been urged against the dukedom patent. Why, it is said, if it was really granted by Charles, was nothing heard of it for sirteen years? To some extent I am inclined to accept Glamorgan's answer that the dukedom was granted conditionally on the service being performed, and that as the service was not performed, he did not claim the reward. Yet, though I think this is the trath, it is, I suspect, not the whole truth. As Carte has observed, the remainder in the patent of dukedom was not as usual to the heirs of Glamorgan's body, but to his heirs male, implying that in case of his own sons predeceasing him the title was to go to his father or his brother.

Is it not possible that the grant of a dukedom to Glamorgan roused some antagonism between himself and his father, who, according to a well-known anecdote, was apt to disapprove of any attempt of the young man to take the lead in his household? As early as 19 June 1643 there appears to have been some thought of conferring the dukedom on the father. Charles had written to Worcester on that date ' ' concerning the changing of your title.' There are signs after the grant of the dukedom to Glamorgan on 4 May 1644, that the old man was not well satisfied. On 2 Aug. 1644, Charles writes to Worcester, ${ }^{10}$ that he is to have the first vacant garter; the garter, it will be remembered, having before been promised to the son. Then on 13 Aug. " Glamorgan writes a letter of affectionate tenderness to his father, from which it is evident that there had previously been some falling out between them, and after this comes an undated letter from Charles to Worcester, in which is the mention of the marriage for the marquis's grandchild already referred to, and also a reference to an inclosure, the contents of which are to be kept secret for the present. Probably the inclosure was a warrant-which is printed in Dircks's Life-to the attorney or solicitor general to prepare a bill for the king's signature creating Worcester, not Glamorgan, dnke of Somerset.12 It is dated 6 Jan., the twentieth year of the reign, that is to say $164 \frac{4}{3}$.

All this looks as if there had been something approaching to a family quarrel. Is it too much to suppose that Glamorgan, who, excitable as he was, was an attached and obedient son, had got the king to transfer the dukedom to his father? If this is so, we can anderstand not only why Glamorgan did not present his patent of dukedom for sisteen years, bat why he produced it then. As long as his father lived, the old man had only to send the warrant in his own favour to one of the law officers and to see that the bill

- Dircks, 64.

4 Toid. 103.

" Ibid. 76.

Ibid 104. 
drawn out by them was signed by Charles. A patent would follow in due official course. As soon as Worcester died, the warrant, being granted to him personally, died with him. When Charles II retorned, Glamorgan, now marquis of Worcester, must either give up all hopes of the dukedom or produce the suspicious patent of 4 May 1644. He chose the latter course and signally failed.

There is, indeed, a subsequent letter from Charles to Glamorgan which is not very easy to understand.

What I cen farther think at this point (wrote Charles on 12 Feb. $164)^{\prime \prime}$ is to send you the blue ribbon, and a warrant for the title of duke of Somerset, both which accept, and make use of at your discretion; and if you should defer the publishing of either for a while to avoid envy and my being importuned by others, yet I promise your antiquity for the one and the patent for the other shall bear date with the warrants.

It is possible that the father may have given way, and tarned the honours over to his son, ${ }^{14}$ or it is possible that Charles, foreseeing the likelihood that Worcester might die before he was himself in a position to grant the dukedom, openly wished to assure it to Glamorgan as well. If this is the explanation, Charles's subsequent misfortunes and the failure of the Irish design pat it out of Glamorgan's power to convert the warrant into a patent in the king's lifetime. In any case the interpretation of this letter is immaterial to the main question at issue.13 Hitherto I have treated of the dukedom patent irrespective of the change of date implied in the insertion of the word primo. In this it is as difficult to repel the charge of forgery, as it is to maintain it in respect of the body of the document. I cannot imagine that the insertion can have been made except for a purpose; nor is it easy to suggest a purpose except Glamorgan's anriety to obtain credit for the patent. To the later investigator, to myself even more than to Anstis, 1645 is an impossible date; but to the lords of 1660,1644 was a date which conld only have been made credible if Glamorgan had chosen publicly to reveal what he, after his reboff, made known to

13 Dircks, 74.

11 Yet Glemorgan snbsequently informed Rinuceini that the dutedom was to be his father's. I draw this information trom p. 1100 of the MS. which is usuelly bown as the Rinuocini Irmoirs, which Lord Leicester has bindly allowed to be deposited in the British Maseum for my ase.

is It is also annecessary to go at length into the question of the grant of the earldom of Glamorgan. The one solid thet is that a signed bill granting the earidom was receired at the signet offee in April 1645, and that nothing forther wes done in it. At what provious date the signed bill was granted, wo have no means of knowing. If $\mathrm{mJ}$ contention that the commission of $1 \mathrm{April} 1644$ is genuine be accepted, it must have been before that date. The position of the earldom was a matter of public notoriety. In a catalogue of 'new lords created by the king,' printed in London in Norember 1645 (Civil War Tracts, Brit. Mos. Press-mert E 308, 30), we find 'the lord Herbert, son to the marquis of Worcester, created earl of Glamorgan by bill signed. The earl of Lichfield wes in the same position. Ho was killed at Bowton Heath before he could find money to pay the fees of the patent office. 
Clarendon in the letter quoted in an early part of this article. The date of 1645 , on the other hand-the date when his Irish mission was actually carried out-would seem to the lords to be an exceedingly probable one. We have here, I suspect, the foll ertent of Glamorgan's forgery. There is no wholessle invention of documents; but there is an insertion of a forged word to gain easier credence for what was otherwise a true tale. If Glamorgan had forged the whole patent, he would hardly have directed the clerk who copied it to change his ink at the last word.

I now torn from this preliminary investigation to the main question at isane, Glamorgan's actual mission to Ireland in 1645. It is well known that in the course of that year he signed a peace with the Irish the particulars of which he did not communicate to the lord lientenant, and that he prodaced to them certain documents signed by Charles which, as he contended, anthorised him to enter upon a secret negotiation. On one side it has been held that these documents were forged by Glamorgan, but the prevailing opinion has been that Charles really authorised him to conclude the secret treaty and mendaciously disavowed him when the truth lorked out. I now propose to show that neither of these views is correct, and that all the evidence consistently points to an explanation of a different character from either.

Up to the last days of 1644 we hear nothing of any attempt to employ Glamorgan in any negotiation for a peace in Ireland. The commission of 1 April of that year had reference solely to the command of an army and to the raising of the requisite funds for a military ondertaking. On 27 Dec. 1644 Charles wrote to Ormond ${ }^{16}$ that Lord Herbert, i.e. Glamorgan, was coming to Ireland on private business.

I have thought good to use the power I have, both in his affection and daty, to ingage him in all possible wayes to further the peace there: which he hath promised to doo. Wherfore (as you fynd occasion) you may confidently ase and trust him in this, or any other thing he shall propound to you for my service; there being none in whose honnesty and zeale, to my person and crowne, I have more confidence.

Then follows the well-known ciphered postscript :

His hanesty or affection to my service will not decespe you; bat I will not answer for his judgement.

This postscript has been orged against the view that Charles at this time contemplated the employment of Glamorgan in a delicate negotiation; and though it is true that Charles frequently trusted persons for whose judgment he would have declined to answer, yet it seems hardly conceivable that if this was his opinion of Glamorgan he should have sent him to Ireland to carry on a secret treaty with

4 Carto's Ormond, v. 7. 
the confederates behind the back of the lord lientenant. If, however, he merely meant him to assist the lord lieutenant, and to use his own zeal and opportunities as a catholic with the confederates whilst he was gaided by Ormond's judgment, the objection would fall to the ground; and that this was the true state of the case I hope to be able to show.

In the first place the idea of sending Glamorgan otherwise than as a soldier may be traced to a paper to which, as far as I know, no reference has been made by any previons investigator, but which contains the instructions which Ormond gave on 14 Nor. $1644,{ }^{17}$ to his cousin Barry, whom he then sent on a private mission to the king. Barry is there ordered to offer Ormond's resignation of the lord lieutenancy partly on account of his extreme poverty bat also for another reason which concerns us here. Barry is told to besech his majesty to consider what I am or may be forced to do, by way of compliance with the Irish for his service or by his commands, is more subject to misconstraction and in more danger to be disobeyed, then if any other that hath no interest in the kingdom nor any kindred among the Irish should do things of greater favour to them, there being no possibility to asperse such a man of favouring them for any other reason than for the king's service and the preservation of the lingdom.

It therefore follows that when the king wrote on $27 \mathrm{Dec}$. to Ormond announcing Glamorgan's coming, Ormond had already written asking to be superseded by an Englishman. Charles, who declined to accept his resignation, sends him an Englishman to assist him. Further, we see that Ormond disliked being personslly concerned in making certain concessions to the Irish, and thought that an Englishman would be a better person to take this business on himself. If Glamorgan was to do this Ormond might, as he desired, keep in the background and guide Glamorgan with that judgment in which Charles acknowledged bis new emissary to be deficient.

Such, at least, is what I should expect, if I had to rely on these papers alone. This, however, is far from being the case. We now come on a series of remarkable documents, which have been exsmined over and over again, but which it is necessary for us to examine once more.

First come the king's instructions to Glamorgan, ${ }^{13}$ dated 2 Jan. 1644. A great part of them is concerned with matters relating to the army which Glamorgan was to commend, and to the peerages which he was to grant. These clauses need only be men-

"Carte MISS. riii. fol 162. This is the draft and is andated. In rol. Iri. tol. 211 is s later copJ dated 14 Nov. 1645. The jear is plainly wrong, as wo boow that Barry went to England at the end of 1641; bat the day of the month mag be safely adopted. Bee the king's lettar to Ormond, which is a duplicate of one written on 15 Dec. Carte's Ormond, 7. 9.

1. Dircios, 73. 
tioned here as singularly confirmatory of the genuineness of the commission of 1 April 1644. It is the first clause with which we have to do, as bearing upon the peace negotiation. It runs as follows:

First, you may engage your estate, interest, and credit, that we will most really and punctually perform any our promises to the Irish, and as it is necessary to conclude a pesce suddenly, ${ }^{19}$ whatsoever shall be consented unto by our lientenant, the marquis of Ormond, we will die a thousand deaths rather than disannol or break it; and if upon necersity anything be to be condiscended unto and yet the lord marquis not willing to be seen therein, or not fit for us at the present publioly to own, do you endeavour to supply the same.

Even taking this by itself, it may safely be said that it contains no one word anthorising Glamorgan to treat independently of Ormond. Yet if there could be a doubt, it vanishes upon comparison of this part of the instructions with Barry s paper. We have the king's mode of answering Ormond's own proposal. Glamorgan is not to supersede him, but to assist him.

The next document is a commission dated 6 Jan., of which we have only a Latin translation given by the author of Lord Leicester's manuscript. 20 This, however, does not relate to the negotiation, but authorises Glamorgen to levy troops vel in nostro Ibernia regno, aut aliis quibusvis partibus transmarinis, the levy of foreign troops with money advanced by French catholics being at this time, as we know from other sources, an object of the queen's diplomacy.

This commission, according to the anthor of the manuscript, was sealed with the great seal and countersigned Willis, being in this respect similar to the dukedom patent of the preceding year.

Nest come the often-quoted powers of 12 Jan.: ${ }^{21}$

So great is the confidence we repose in you, as that whatsoever you shall perform, as warranted under our sign manual, pocket signet, or private mark, or even by word of mouth, without further ceremony, we do on the word of a king and a christian, promise to make good to all intents and purposes, as effectually as if your authority from us had been under the great seal of England, with this advantage, that we shall esteem ourself the more obliged to you for your gallantry, in not standing upon such nice terms to do us service, which we shall, God willing, reward. And, slthough you exceed what law can warrant, or any powers of ours reach unto as not knowing what you have need of ; yet it being for our service, we oblige ourself not only to give you our pardon, but to maintain the same with all our might and power.

That these words are perilously wide is beyond question; but is there any reason to believe that they had anything to do with the Irish peace? Not only do they seem much more appropriate to
19. I. soon.
- Lord Leicoster's MSS. tol. 713.
31 Dircks, 79. 
the negotiations which Glamorgan would have to carry on with foreign powers for the money with which the foreign levies were to be psid, but the document in which they occur was not adduced by Glamorgan himself as the ground on which his treaty with the Irish was founded.

Here is what Glamorgan subsequently wrote to Clarendon in explanation of certain parts of the commission of 1644 :

The maintenance of this army of foreigners was to have come from the pope and such catholic princes as he should draw into it, 23 having engaged ${ }^{24}$ to afford and procure $80,000 \mathrm{l}$. a month; out of which the foreign army was first to be provided for; and the remainder to be divided among other armies. And my instructions for this parpose and my powers to trest and conclude thereupon, were signed by the king under his pocket signet, with blanks for me to pat in the nsmes of the pope or princes, to the end the ling might have a starting hole to deny the having given me sach commissions, if excepted against by his own subjects; lesving me as it were at stake, who for his majesty's sake was willing to andergo it, trusting to his word alone.

After this, I feel little doubt that the powers of 12 Jan. were not connected with the Irish negotiation, but with the financial arrangements with the pope and catholic princes.

The really important document for our purpose is that of 12 March, as it was this which was produced by Glamorgan as the basis of his treaty with the confederate catholics.

We ... do by these (as firmly as under our great seal to all intents and purposes) anthorise and give you power, to trest and conclude with the confederate Roman catholies in our kingdom of Ireland, if upon necessity any be to be condescended unto, wherein our lientenant cannot so well be seen in, ss not fit for as at present publicly to own. Therefore we charge you to proceed according to this our warrant, with all possible secrecy ; and for whatsoever you shall engage yourself, upon such valuable considerations as you in your judgment shall deem fit, we promise on the word of a king and a christian, to ratify and perform the same, that shall be granted by you, and onder your hand and seal; the asid confederate catholics having by their supplies, testified their zeal to our service.

That this document was genuine there can be no reasonsble doubt. It was formerly in the hands of Lingard and afterwards in those of Canon Tierney. What became of it afterwards I have been unable to discover, but I have in my possession a photograph taken of it by Mr. Brace whilst it ${ }^{2} 8 \mathrm{~s}$ in Canon Tierney's possession. The highest anthorities assure me thst there can be no doubt about its being actually signed by Charles, and the only question is whether

- Clar. St. Papers, ii. 202.

- There is nothing starting in this to those opho frow the proposials made with the queen's enthority to the pope by Sir Kenolm Digby in 1646.

in I I hering engaged. 
the body of the document is not also in Charles's handwriting. Unfortunately, the photograph itself is now too faded to admit of reproduction by photography, but a facsimile, prepared by the ordinary process, is published with the present article.

Of this document, it might be enough to say that powers are limited by instructions, and that however enormons is the authority conveyed, Glamorgan would be bound only to use them in assisting Ormond as he was there directed to do : yet it may be observed in passing that these powers of $12 \mathrm{March}$ agree with the instructions of $12 \mathrm{Jan}$. in contemplating a co-operation with Ormond, not an action taken behind his back.

If, however, it be acknowledged that these powers do not contemplate any action independent of the lord lientenant, it may be said that it is immaterial whether they do or not. The real point at issue, it will be urged, is whether or not Charles gave verbally to Glamorgan secret instructions to proceed independently. It will narrow the inquiry into this suggestion if we remember that the concessions in Glamorgan's subsequent tresty, which were not in accordance with those which Ormond was ready to make, were two : (1) the surrender to the catholics of the churches in their possession, and (2) the abandonment of the jurisdiction of the protestant clergy over the catholics.

In the spring of 1645 the question of the churches had not been even mooted, and as to the question of jurisdiction it was being fought ont on quite different lines, the point at issue being the jurisdiction of the king, which the Irish wished to overthrow by the repeal of the acts of premunire and appeals. It is, therefore, hard to understand how Charles could have verbally anthorised Glamorgan to make concessions which were not yet demanded, though he may have given him a wide latitude to act as occasion served. Of the probabilities of this latter supposition we shall see more if we trace the king's policy as revesled in his correspondence with Ormond.

On 15 Dec. $1644^{2}$ Charles had informed Ormond that he was ready to agree to the immediate suspension of the penal laws in Ireland, and even to their repesl whenever he was restored to his rights with the aid of Irish arms. 'Bat all those,' he added, 'against appeals to Rome and premunire must stand.'

How stannch he was in this matter of jurisäiction appears from his letter of $27 \mathrm{Feb}$. in which he announces to Ormond his readiness, if it is absolutely necessary, to consent to an immediate repesl of the pensl laws instead of writing till a victory had been gained.

I think (he writes ${ }^{25}$ ) myself bound in conscience not to lett slipp the meanes of settleing that kingdome, if it may be lawfully, under my obedience, nor loose that assistance which I may hope from my Irish subjects, 
for such scruples, as in lesse pressing condition might reasonably be stucke st by me for theire satisfaction: I doe therefore commande you to conclude a peace with the Irish, whatever it cost; soe that my prorestant subjects there may be secure, and my regall authority preserved. But for all this, you are to make me the. best bargaine you cann, and not to discover your enlargement of power till you needs must. And though I leave the manageing of this greate and necessary woorke entirely to you, yett I cannot bat tell you, that if the suspention of Poinings' act for such bills as shal be agreed appon betweene you there, and present takeing of the penall lawes against papistes by a lawe will doe it, I shall not think it a hard bargaine.

The important thing here is not that Charles had gone a step further than he had gone in December by offering the immediate taking away of the penal laws, bat that he evidently contemplates this offer as the extreme limit of concession. Ormond is to drive as good a bargain as he can-that is to s8y, is not to go so far as that if he can help it, and even in giving these orders he throws out a reminder that his regal anthority is to be preserved, or in other words that the acts of premunire and appeals were to be untouched. Is it to be supposed that he was at the same time privately authorising Glamorgan to purchase a peace at any price? If so, why did he pile ap difficalties for himself by asserting to Ormond that he was not to be induced to give way on that point? If his letter to Ormond had been a pablic docament the donble language would have been intelligible. It is the fact that it was not a public docament which creates the difficalty.

On my supposition that Glamorgan was to assist Ormond in urging the confederates to be content with this proposed repeal of the penal laws, there is no difficulty at all, especisilly as on 27 Feb. and even on 12 March Charles was still in ignorance of the way in which Ormond would take the rejection of his proposed resignation." Glamorgan, as is well known, sailed from Carnarvon for Ireland on 25 March, bat being driven by a storm on the Lanceshire coast, made his way across country and songht refuge in Skipton castle.

Here arises a fresh question, which has been often asked bat never answered. Why is it that if Glamorgan was trusted with a secret mission of such tremendous importance, he was allowed to stay in England for three months after his shipwreck, apparently without the slightest attempt being made to hasten his departure? $I$, at all events, find no difficulty. As soon as Charles became aware that Ormond did not insist on resigning and was quite ready to take up the negotiation on Cherles's terms, there was no immediate necessity for Glamorgan's presence in Dablin. I must leave

$n$ Barry did not reach Dablin on his retum from Englend till 6 March. Ormond to Diabs, 28 Marah, Carte's Ormond, vi 272 
it to those who thinlr that Glamorgan was to have given a secret consent to much more than this to explain his delay as best they can.

It was not for some weeks that any hitch in Ormond's negotiation appeared. On $8 \mathrm{May}$ the lord lieutenant informed the king of the state of affairs. ${ }^{23}$ From this letter it appesred that though Ormond had taken up the negotiation, he shrank from carrying it on further without the approbstion of the privy council at Dublin, ' without whoes approbation all further concessions to the Irish, as I hambly conceive, will be dangerous and ineffectual to all your majesty's purposes.' He said that he had read to the council the duplicate of the letter of 15 Dec., but he had not read to them another letter enlarging his powers, which was no donbt that of $27 \mathrm{Feb}$. He had given dissatisfaction to the catholic agents by trying to carry out the king's instructions to hold back his final offer of the immediate repesl of the pensl lsws, and it was perhsps his wish to conceal that he was permitted to offer this, before he was actually driven to do so, that led him to withhold the letter which contained the permission from the privy council.

At all events this despatch from Ormond made it finally plain that if Charles's business was to be done, Ormond was not the man to do it. He was too honourable and straightforward to make a good diplomatist of the kind Charles needed, and it may be added that he had too little intellectral originality to convey any positive recommendations of the. kind which Charles had once been in the habit of receiving from Strafford.

Ormond's despatch of 8 May was received by Charles on or shortly before 21 May. 20 When it arrived Charles was in the thick of the Naseby campaign, and it is no wonder that he merely expressed his confidence in Ormond without immediately taking any forther steps in consequence of what he had heard. On 14 June, however, he suffered the crushing defeat of Naseby, when his cavalry was routed, and his infantry was almost entirely destroyed. It then becsme of more pressing importance than before to hurry on the Irish treaty in order that 10,000 Irish soldiers might land in England. Accordingly we have a letter from him on 23 June, expressing his pleasure that Glamorgan was already 'gone for Ireland.' The letter requesting him to go must have been written some dsys before.

Whether Charles gave any fresh instructions to Glamorgan wo cannot say certainly, but no word of information has reached us to show that he was in Charles's presence at any time since March, and if there had been instructions in writing they would surely have been produced to the Irish negotiators, and we should have heard of them from that side. Curiously enough Glamorgan was not the only secret

$=$ Carto's Ormond, ri. 278.

- Digby to Ormond, 21 Mag, Carto's Omond, vi. 287. 
negotiator despatched at this time to forward the treaty. Colonel Fitzwillisms, who had come from France recommended by the queen, was sent over at the same time, and it is to be observed that in conversation with him ${ }^{31}$ Ormond, in compliance with the king's latest direction to him to bargain, absolutely denied that he had been instructed even to take off the penal laws. Fitzwilliams's letter is also interesting in showing that a new point had been raised. He had been anthorised to offer ' free use of religion, a free parliament, and the penal laws to be taken off.' The Irish now told him that they understood these to include the retention for the catholic church of the churches which they actually held, that is to say about ninetenths of the churches in Ireland. This subject, as we know from another source, had been discussed in May at Kilkenny; and though there was some difference of opinion as to the mode in which the claim was to be made, all were of opinion that it must be enforced. What is equally to the porpose is that the claim for the release of the Irish catholics from the jurisdiction of the protestant clergy made its appearance in a paper presented at Dublin on 20 June, and it therefore follows that on this head, as well as on that of the churches, Charles could not, even when Glamorgan finally started, have been in a position before 23 Jane to instract Glamorgan either verbally or in writing to gire way on two points of the raising of which he was at that time ignorant. Fet it was the acceptance of these very two points in the subsequent Glamorgan treaty, which distinguished it from that which Ormond, by the king's instructions, was prepared to aign. Wie have now, therefore, conclusive evidence that if Glamorgan carried out the king's wishes, it could not have been in consequence of verbal instructions given him in Jone.

When Glamorgan arrived at Dablin in August he found the negotiations almost at a standstill. In a discussion held on $22 \mathrm{July}$ the Irish agents had insisted

that their religion being made by bull from the pope in this hingdom might be free from the danger of the ancient statutes made before the twentieth year of Henry VIII and the statutes made since; that their bishops might exercise jurisdiction over their clergy and people 88 to correct manners, and that if two or more of their priests were in competition about their rights to any pariah, their bishops might have power to determine controversy of that kind; that their party might be exempt from the jurisdiction of the protestant alergy ; that the probate of wills, certifying of matrimony, bastards, and matters of titbes, may be decided by commission derived from his majesty; that the tithes of the clergy might be wholly employed for his majesty's service during the wars; that the Roman catholic subjects might enjoy the charches within their quarters.

"Pitenilliams to Digby, $16 \mathrm{July,} \mathrm{S.P.} \mathrm{Dom} \mathrm{F} \mathrm{Lord} \mathrm{Leicestor's} \mathrm{MSS.} \mathrm{p.} 890$ b.

- Requests of bis majesty's Roman catholie stajectos 20 June, Carte MSS. xr. tol 92. 
The request for the abolition of the jurisdiction of the king or of the clergg, and for the retention of the churches, Ormond refused to grant.

With respect to the churches Charles was peremptory. On 31 July Charles wrote to Ormond ${ }^{u}$ that he would make no new concessions in matters of religion further than to allow the erection of Roman catholic chapels in parishes where "the much greater number are papists.'

But (he sdded) I will rather chuse to suffer all extremity then ever to abandon my religion, and particularly either to English or Irish rebells; to which effect I have commsnded Digby to write to their agents that were employed hither.

Digby's letter to the agents ${ }^{35}$ is in the strongest possible terms. It is difficult to suppose that Charles would have expressed himself as he did to Ormond, if he had already privately authorised Glamorgan to conclude a tresty granting what he now said it was hopeless to expect of him.

So far we have been concerned with the probabilities of the case on Charles's aide. Let us now torn to watch Glamorgan's proceedings. Of his part in the negotiations which Ormond was still carrying on when he arrived in Dublin we know nothing, but on 11 Aug. Ormond gave him a most flattering letter of introduction to Lord Maskery, $\infty$ who with the other agents hed returned to Kilkenny to be present at the meeting of the general assembly, to which Glamorgan quickly followed them.

The result of this mission was the celebrated Glamorgan treaty, signed 25 Aug., in which Glamorgan engaged in the king's name, in addition to the concessions which Ormond had already made, to abandon the churches, and to grant, not indeed the repeal of the acts of premunire and appeals, but a freedom of Roman catholics from the ecclesiastical jurisdiction of the protestant clergy. In consideration of this the confederate catholics were to send over 10,000 men to serve the hing under Glamorgan himself.

The authority which Glamorgan produced was the warrant of 12 March. I have already given reasons for believing that that warrant was not intended to anthorise him to make these two concessions, and I need not repeat them here. It is enough now to ask whether Glamorgan acted as if he believed himself to be so anthorised. From this point of riew it is remarkable that the first thing be did after signing the treaty was to sign the following protesta. tion : 7

I Edward Earl of Glamorgan do protest and swear faithfully to acquaint the King's most excellent Majesty with the proceedings of His

" Carte's Ormond ri. 305.

D Digby to Mastery and others, 1 Ang, Carte's Ormond, vi. 309.

- Birch's Inquiry, 68.

s Cox, Hib. Anglicara, i app. 117. 
Kingdom in order to his service, and to the indearment of this nation, and punctual performance of what I have (as authorised by His Majesty) obliged myself to see performed, and in default not to permit the army intrusted into my charge to adventure it self, or any considerable part thereof, until conditions from His Majesty, and by His Majesty be performed.

Gramorgan.

This might be interpreted as simply intended to appease the confederates, but the same cannot be said of the defeasance which follows and which was signed on 26 Ang.

After stating that an agreement has been concluded, the docament proceeds as follows: 28

Yet it is to be understood that by the said agreement the $\mathrm{B}^{\mathrm{t}} \mathrm{H}^{\mathrm{B}}$ blo Edward Earl of Glamorgan doth no way intend to oblige his most excellent Majesty, other than he himself shall please, after he bath received these 10,000 men, . . . yet the said Earl of Glamorgan, doth faithfully promise upon his word and honour, not to acquaint his most excellent Majesty with this defezance until his Lordship hath ondesvoured, as far as in him lies, to induce his Majesty to the granting of the particulars in the said articles of agreement, but that done, according to the trust we repose in our very good Lord the Earl of Glamorgan, we the said Richard, Lord Viscount Mountgarret \&c. and every of as, for, and in behalf of the Confederate Catholicks of Ireland, who have intrusted us, do discharge the said Earl of Glamorgan, both in honour and conscience, of any further ingrgement to us herein, though His Majesty be not pleased to grant the said particulars in the articles of agreement mentioned; and this we are induced to do by the particular trust and confidence, the said Earl of Glamorgan hath reposed in us for the draught of the Act of Parliament; ... and we are also induced hereunto, in regard the said Earl of Glamorgan heth given us sssurance upon his word and honour, and upon a voluntary ath of his, that he would never to any person whatsoever discover the defezance in the interim, without our consents : and in confidence thereof we have hereunto set our hands and seals \&c.

Even more striking than the contents of this curious document is the omission of that which one would most expect to find there. Glamorgan is quite ready to give his word and honour upon various points, but there is no hint here or anywhere else that he gave his word and honour that the king had verbally anthorised him to make the two concessions which form the backbone of the secret treaty; and if he did not, what other conclusion is possible, except that Charles never had done so?

Having thus shown the difficulties in the way of the conclasion either that Glamorgan forged the documents which he produced, or that he was verbally instructed to make the treaty of 25 Ang., I may ask whether we may not solve the problem by a very simple if conjectural explanation. 3

2 Cox, Bib. Anglicana, i. epp. 117.

- I have taken no notice of a letter trom the king presented by Glamargan to 
Glamorgan, according to my riew of the case, was sent over in March to take command of an army composed of Irish and others, and also to smooth the way for Ormond's negotiation of a treaty of peace by assuring the Irish that Charles would really grant them relief from the penal laws. When he reached Dublin in August he had the same mission; but he soon found that the conditions of success were changed. Unless the two points above mentioned were granted there would be no peace, and no army for him to bring over to England. Ormond, if he had been in his case, would have stopped the neyotiations for farther instructions. Is it so very anlikely that Glamorgan preferred to draw instractions which he had never received out of the almost boundless powers which he actually possessed, just as in 1660 he did not scruple to add primo to the date of his patent, not to obtain something which the king had not granted, but to make it easier for him to obtain that which had actually been intended for him. Charles was being ruined in England, and Glamorgan-who being a catholic would be anable to understand Charles's religious scruples, and who had the double object before him of saving the monsirchy and exslting his own church-would save hin in spite of himself. When once there was an Irish army in England, and perhape an army of continental catholics as well, ${ }^{40}$ Charles would forget his scruples.

In proposing this explanation, I have been not unmindful of Glamorgan's character us it is revesled in his correspondence with Ormond, a great part of which lies still unpublished amongst the Carte MSS. His further proceedings would form a not uninteresting story, but to recount them would make too long an already lengthy article. It will be sufficient if $I$ show from other sources that Glamorgan wass apt to act in the king's name without any attempt to ascertain the king's wishes.

In December 1645, after his treaty had been discovered and denounced by Ormond, Glamorgan was at Kilkenny, hoping that the supreme council would hasten the levy of the army to be placed under his command. The council was by this time ready to accept Ormond's terms, in the expectation that they would be supplemented by Charles's acceptance of Glamorgan's treaty. The nuncio Rinuccini, who had arrived in Kilkenny since the signature of that treaty,

the nuncio. It has been correctly said that its longage and its date are inconsigtent with the supposition that it proceeded trom Charles bimself. The obvious explanstion is that it we written by Glemorgan's secretery on a blank signed by the king. Some criticisme on the language of this and other docnments connected rith this affir rould lead one to suppose thet those who make them imagine that Charles wrote formel docoments with his own hand. The flowery lengange of the patents is no doubt treceable to Glemorgen; bat thet is only what is to be expected.

- Domoulin, the Fronch agent, in his despateh of Mrerch $\frac{14}{14} 1646$ (drehives des Af. Etrangetra), askb Jlararin at Glemorgan's request for 2,000 Liegeois. This, it will be remembered, is the number mentioned in CHemorgan's letter to Clarendon. another nedesigned coincidence berring testimany to its accuracy. 
was dissatisfied, and wished Charles to make further concessions still. As he could not move the supreme council to ask for them, he applied to Glamorgan, and Glamorgan's answer was as followr: 41

Anno Selatis 1645, 20 Decambris.

10. Modo Pax publico edicto promulgetar ac decem millia militum transmittantor in Angliam, articuli nolli evulgabontur donec privatm concessiones 12 a Rege rats habeantur. Quod fiet quam primum terram attigerint prædicti milites absque ultariore allo eventus discrimine, nisi quod fretum riginti quatuor horarom spatio trajicere debeant.

20. Cum Marchio Ormonim tam Commisearins Regins, quam Prorex sit, cumque duplax ills potestas conjungi debest at Pacis articali effectum consequantar, rem totam fanditus deskruet ai none vel mentio fiat de Catholico Prorege. Posten vero ex me suscipiam, Deo favente, Regem, initio a me vel ab alio Catholico sompto, privatim se obligaturom alium quam Catholicum Proregem deinceps nollum in hoc Regno nominandum, atque Episcopos Catholicos, tom etiam in Parlamentum admittendos, eumque in finem confestim Parlamentum convocandum : quod soavius et facilius feri poterit, abi leges hajus Begni, quibus Cetholici redduntar regiminis incapaces, quæque adhuc vim suam obtinent, sbrogatm fuerint, quod in se Marchio recipit prestandom quodque melius et efficacius procurare potarit, quam si Catholicus esset.

80. Statuts seu leges Academim Orthodox' erunt et Cstholico.

$4^{\circ}$. Post conclusionem et ante confirmationem articulorum, si intarim confosderatorum Catholicorom armis loous vllus ab hoste recuperetar, quod ad religionem Catholicam spectat, esdem ratio habebitur, quam nunc ineunt in ditione sibi subjects.

Oltimo quod ad regiminis modum sttinet, consilii supremi corpas integrum permaneat, cum es jurisdictione quam nuno habet, et $D$. Prorex nollam jurisdiotionem ant acquirat ant exerceat, quam nune non habet vel erercet, donec privato concessiones rats habeantor.

Prodictas omnes condiciones fidelisaime prestans enitar Deumque testor nisi Illustrissimus et Beverendissimus Nontias adesset, nollis ex hisce conditionibus assentiri me potuisse.

Qum vero rudiore jam forma et indigesta exposai abi per liberius otium licuerit in ordinem accurationem redigi curabo.

Hisce interim tanquam summis rerum capitibus strictim propositis subscribo.

Guamoraastos.

This second secret treaty of Glamorgan, which did not see the light, explains much in the first secret treaty which was soon to be made public. Written on the spur of the moment, and certainly without time to consult the king, it can only have been founded, if it was founded on anything except Glamorgan's zeal for his church, on a general power from the king to act as he saw fit. This is precisely what Glamorgan claimed to have. He laid before the nancio a summary of the powers given him by the king, amongst which is the following: 13

1 Lond Inicester's MfS. fol 10246. a Is the Giemargen treaty.

- Lord Lricester' MSS. p. 1004. 
Est mihi potestas in Iberniâ faciendi concessiones (in Proregis supplementum) Catholicoram gratiô juxts obsequium quod nune sum Majestati me interveniente præstiterint, ant secundom auxiliom ab ullo alio Principe Catholico in eorum gratiam in Anglis subpeditandam, idque sine relatione ad ullum alium, ea lege at negotiom secretum teneant doneo copiæ meæ apparnerint.

This evidently refers to the powers of 12 March. As we hsve already seen, if they are taken by themseives those powers might authorise Glamorgan to do anything. Taken with the instructions they authorised him to do anything of which Ormond approved. Glamorgan acted on his powers, but gave no heed to bis instructions."

Turning back again from Glamorgan to Charles, let us finally ask what the hing had to say about the matter. Of his public announcement, or even of his letters to Ormond, it is nnnecessary to speak ; but if we want to bnow the real trath about Charles, we naturally turn to his letters to his wife. From her he had no secrets, and in writing to her no reason to paint himself other than he was. When he tells her that a thing is so and so, we may conclude that it was so, except so far as we may allow a margin for his habit of selfdeception. What he told his wife, let the following extracts show.ts

Ifarch 3, 164 $\frac{\pi}{6}$. -And now I come to answer the particular concerning the E. of Glamorgan, the conclusions whereof are so strangely raised upon the premises that I know not what to say to them, they are so much against the way of my reason. For must I be thought an enemy to the Roman Catholicks, because I will not consent to the destruction of the Protestants in Ireland ; or, because I have disavowed that which is directly againgt my constant professions, am I therefore likely to disavow thee? In a word, my answer is this, that the same reason which made me refuse my consent to the establishing of the Presbyterian government in England, hath

* It can herdly be thought necessary to adduce further proof of Glemorgan's headlong character. Yet it is not withont interest to noto that at the end of January 164 Rinuccini recaived trom Rome a copy of certain articles which hed been proposed to Sir Kenelm Digby by Pope Innocent Z (Rinuccini, Nursiatura, 459.) According to these, not only the churches in the hends of the canfederates, but all the churches in Iroland were to be restored to the catholies, and Dablin together with all the places heid by Ormond were to be surrendared to them, Ormond himself rexigning his post to a ner catholic lord lientenant. Glemorgan at once, et Binnccini's instance, proposed to send his brother Lord John Somerset with a copy of these articles to the king non alid formd quam si intor Dominationem pestram Inustrisimam at me inita fuissent virtute auctoritatis mihi facta a rage et securitatis Dominalioni vestre Mlustrissima data per propriam regis epistolam, ita ut ha pactiones a rege confirmentur antoquam receurum sit ut alia militum soptena millia transmittantur. (Glamorgan to Rinuccini, Feb. 6, 164f, Lord Leicester's MSS. fol 1069.) In otber words, just as he had promised to arge the ling to sceept the treaty of August 1645 as having been drawn up in consequence of the powers given to him, he was now to urge the king to accept this prepostarous arrangement agreed to by Sir K. Digby and the pope, as if it had been hatched in Ireland as the outcome of the same powrer. Here again we see the work of the man who subsequently added the word primo to a parent.

4 Cluates $I$ in 1646, Camd. Soc. pp. 21, 25, 27. 
likewise made me disavow Glamorgan in his giving aray the Church lands in Ireland, and all my ecclesiastical power there, besides my exposing all my friends to ruin, both being equally and directly against my conscience, which when I shall forfeit, by giving op the Church of England to either Papists or Presbyterians, I must not expect to be esteemed by honest men, or (which is worse) ever to enjoy God's blessing.

March 12.-I believe I did well in disevowing Glamorgan (so far as I did) : for though I hold it not simply ill, but even most fit, upon such a conjuncture ${ }^{46}$ as this is, to give a toleration to other men's consciences that cannot make it stand with mine to rield to the rain of those of mine own profession, to which if I had assented, it then might have been justly feared, thet I, who was careless of my own religion, would be less careful of my word.

March 22.-I find that Sir Edw. Nicholas his gloss apon the Lord Glamorgan's business bath made thee apprehend that I had disarowed my hand, bat I assure thee I am very free from that in the onderstandings of all men here, for it is taken for granted the Lord Glamorgan neither connterfeited my hand, nor that I have blamed him for more than for not following his instructions, as Secretary Nicholas will more at large show thee.

Equally to the point is Charles's language to Glamorgan himself. Writing on 3 Feb. 1646 he says: 47

I must clearly tell you, both you and I have been abused in this business; for you have been drawn to consent to conditions much beyond your instructions, and your treaty hath been divulged to all the world. If you had advised with my Lord Lieutenant (as you promised me) all this had been helpod.

These extracts ought to settle the question. Charles, writing under circumstances which bound him specially to truthfulness, gives precisely the same explanation as that which has been drawn from the negotiation itself.

Of the way in which Charles disavowed Glamorgan much might be said if the purpose of this article were to discuss Charles's character. It is enough to remember that Glamorgan personslly was not a sufferer, except 80 far as the failure of his plans made him one. Charles did not-as Elizabeth punished Davison-punish a faithful servant who had exceded his instructions in reliance on the rague and anlimited powers with which he had been entrasted.

Samukt R. Gardinir.

- 'Conjecture' in MS. "Dirabo, 184. 